\title{
Modelling the Formation and Maintenance of Headland Associated Linear Sandbanks
}

\author{
A/Prof C Pattiaratchi \\ Centre for Water Research \\ The University of Western Australia, \\ Nedlands, 6907, \\ Australia. \\ phone: (+61-8) 9380-3179 fax: (+61-8) 9380-1015 e-mail: pattiara@cwr.uwa.edu.au \\ Dr Peter Harris \\ Australian Geological Survey Organisation \\ Antarctic CRC, University of Tasmania \\ Hobart, 7001, \\ Australia. \\ phone: (+61-3) 6226-2504 fax: (+61-3) 6226-2973 e-mail: P.Harris@utas.edu.au \\ Award Number: N000140110368 \\ http://www.cwr.uwa.edu.au/
}

\section{LONG-TERM GOALS}

To investigate, using field and numerical modelling approaches, coastal physical oceanographic and sediment transport processes in estuarine, nearshore and continental shelf regions.

\section{OBJECTIVES}

Sandridges or Linear sandbanks are located globally in areas where there are strong currents and an abundance of sand (Pattiaratchi and Collins, 1987). They are present on continental shelves, near coastal regions, in embayments and in estuarine regions. The objectives of this project are to: (1) develop a morphological model will be which allow dominant hydrodynamic and sediment transport processes leading to the formation of headland associated linear sandbanks to be determined; (2) extend the morphological model to include estuary mouth sandridges; (3) determine the importance of surface gravity waves in the formation and location of sandridges; and, (4) apply the model to south Florida mine burial observation site, as well as other areas of course-grained nearshore sediments identified by the Mine Burial Prediction Program for study.

\section{APPROACH}

To investigate the hydrodynamic and sediment transport processes responsible for the formation of headland associated linear sandbanks, a morphological model will be developed. The morphological model will include models of hydrodynamic and sediment transport processes coupled through a bottom evolution module based on sediment conservation (de Vriend et al., 1993). In this project, we aim to develop a model that includes the feedback processes between morphology and hydrodynamics to examine the formation of tidal sandbanks. 


\section{Report Documentation Page}

Form Approved

OMB No. 0704-0188

Public reporting burden for the collection of information is estimated to average 1 hour per response, including the time for reviewing instructions, searching existing data sources, gathering and maintaining the data needed, and completing and reviewing the collection of information. Send comments regarding this burden estimate or any other aspect of this collection of information,

including suggestions for reducing this burden, to Washington Headquarters Services, Directorate for Information Operations and Reports, 1215 Jefferson Davis Highway, Suite 1204, Arlington

VA 22202-4302. Respondents should be aware that notwithstanding any other provision of law, no person shall be subject to a penalty for failing to comply with a collection of information if it

does not display a currently valid OMB control number.

\begin{tabular}{|c|c|c|}
\hline $\begin{array}{l}\text { 1. REPORT DATE } \\
\text { SEP } \mathbf{2 0 0 2}\end{array}$ & 2. REPORT TYPE & $\begin{array}{l}\text { 3. DATES COVERED } \\
\mathbf{0 0 - 0 0 - 2 0 0 2} \text { to 00-00-2002 }\end{array}$ \\
\hline \multirow{3}{*}{\multicolumn{2}{|c|}{$\begin{array}{l}\text { Modelling the Formation and Maintenance of Headland Associated } \\
\text { Linear Sandbanks }\end{array}$}} & 5a. CONTRACT NUMBER \\
\hline & & 5b. GRANT NUMBER \\
\hline & & 5c. PROGRAM ELEMENT NUMBER \\
\hline \multirow{3}{*}{\multicolumn{2}{|c|}{ 6. AUTHOR(S) }} & 5d. PROJECT NUMBER \\
\hline & & 5e. TASK NUMBER \\
\hline & & 5f. WORK UNIT NUMBER \\
\hline \multicolumn{2}{|c|}{$\begin{array}{l}\text { 7. PERFORMING ORGANIZATION NAME(S) AND ADDRESS(ES) } \\
\text { Centre for Water Research,,The University of Western } \\
\text { Australia,,Nedlands, 6907,Australia, }\end{array}$} & $\begin{array}{l}\text { 8. PERFORMING ORGANIZATION } \\
\text { REPORT NUMBER }\end{array}$ \\
\hline \multirow{2}{*}{\multicolumn{2}{|c|}{ 9. SPONSORING/MONITORING AGENCY NAME(S) AND ADDRESS(ES) }} & 10. SPONSOR/MONITOR'S ACRONYM(S) \\
\hline & & $\begin{array}{l}\text { 11. SPONSOR/MONITOR'S REPORT } \\
\text { NUMBER(S) }\end{array}$ \\
\hline
\end{tabular}

12. DISTRIBUTION/AVAILABILITY STATEMENT

Approved for public release; distribution unlimited

13. SUPPLEMENTARY NOTES

14. ABSTRACT

To investigate, using field and numerical modelling approaches, coastal physical oceanographic and sediment transport processes in estuarine, nearshore and continental shelf regions.

15. SUBJECT TERMS

16. SECURITY CLASSIFICATION OF:

a. REPORT

unclassified b. ABSTRACT

unclassified c. THIS PAGE

unclassified
17. LIMITATION OF ABSTRACT

Same as

Report (SAR)
18. NUMBER OF PAGES

6 19a. NAME OF

RESPONSIBLE PERSON 


\section{Model applications}

After the construction of the model, several model scenarios will be undertaken as follows: 'Idealised' situation: idealised headlands (eg a gaussian shape, rectangular headland); 'Real' situation: This would be similar to the above case, except that the model will be applied to headlands in Shark Bay (off Cape Levillain) and Portland Bill (UK).

\section{WORK COMPLETED}

The hydrodynamic model has been applied to two different cases: idealised gaussian headland and Portland Bill (UK). Sediment transport modules have been developed and the morphological model is being constructed.

\section{RESULTS}

\section{Gaussian Headland}

The hydrodynamic flow past an idealised gaussian headland is shown on Figures 1. It is apparent that an eddy is observed only when the tidal currents reverse from the flood to ebb stage of the tide or viceversa similar to those observed elsewhere (Pattiaratchi et al., 1986; Green, 1998; Pattiaratchi, 1998). During this slack water period, the tidal currents are generally weak (Figure 1). During the mid-flood or mid-ebb stages of the tide, when the tidal currents are strongest (max sediment transport rates) no eddy is formed. The mean bedload sand transport rates over a tidal cycle indicate highest sand transport rates adjacent to the headland (Figure 2). The net erosion and accretion of sand over a tidal cycle indicate erosion of sand adjacent to the headland and deposition off the tip of the headland (Figure 3). Lobes of sediment deposition on each side of the headland are present indicating the initial formation of the sandbank. The results confirm that it is unlikely that the 'flow in a tea-cup' analogy is applicable for the formation of sandbanks (Pingree, 1978) although this theory has been generally accepted as the only plausible mechanism for the formation of such sandbanks (Wright, 1995).

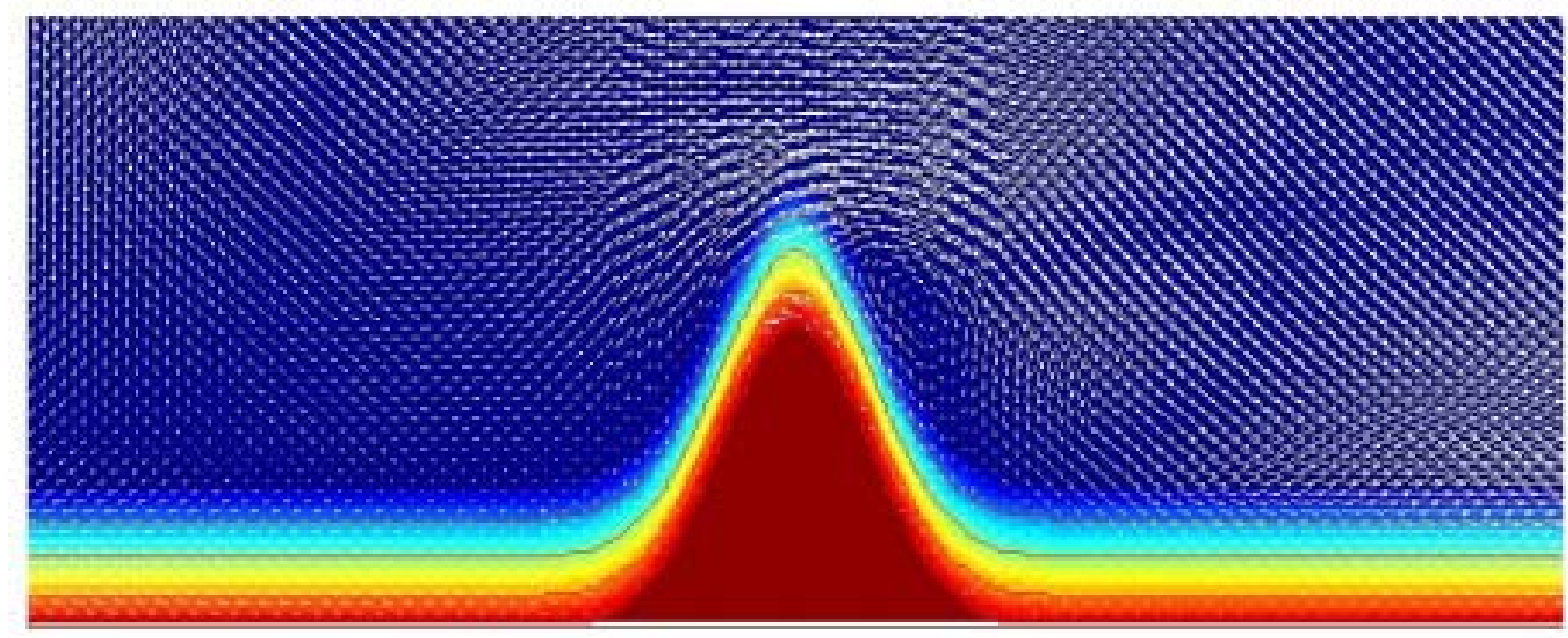

Figure 1. Flow past the gaussian headland at slack water. [Figure showing eddy on the lee of the gaussian headland at slack water] 


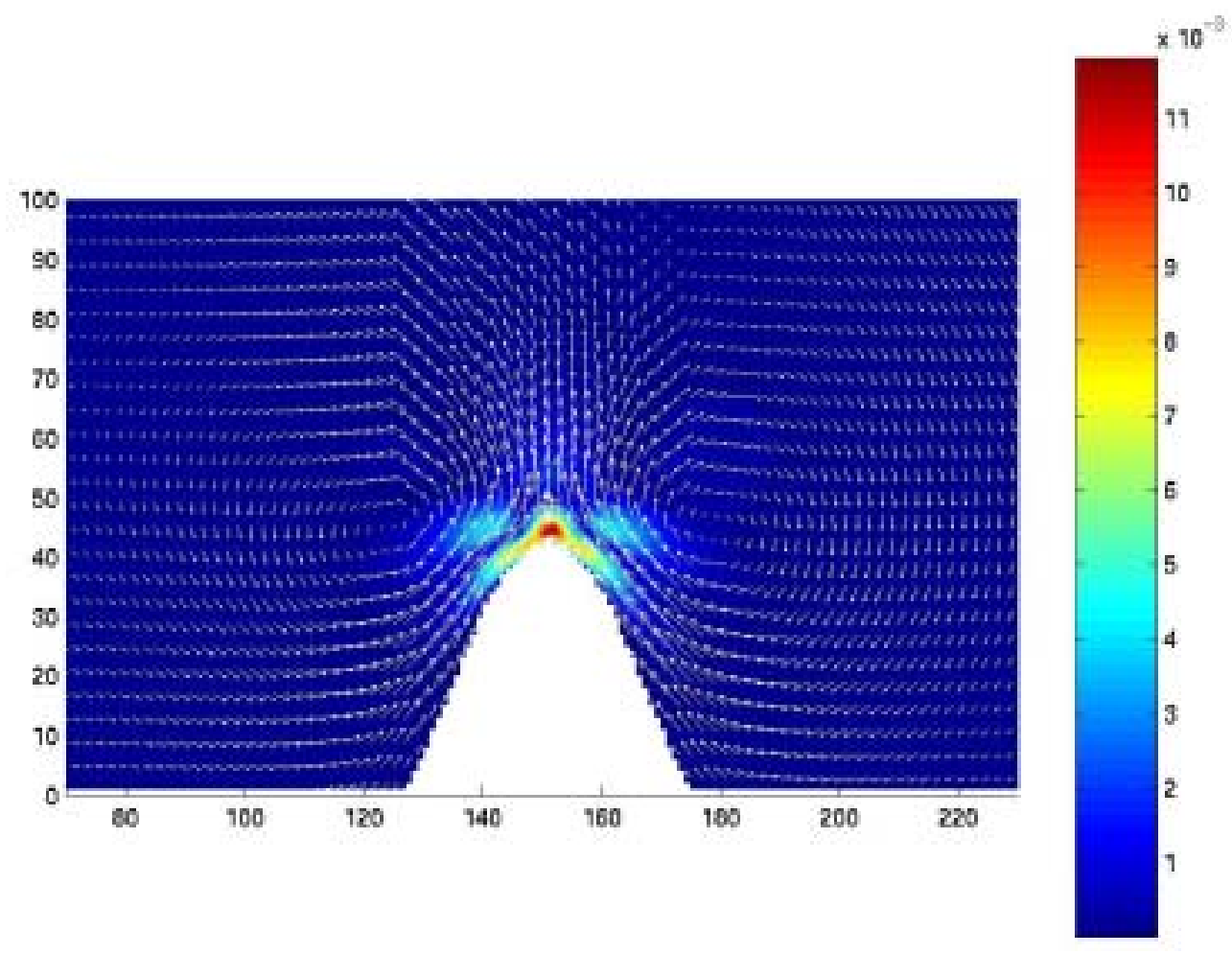

Figure 2. Net sand transport rate over a tidal cycle in the vicinity of the gaussian headland. [Figure showing net sand transport rates in the vicinity of the gaussian headland showing areas of highest transport adjacent to the headland]



Figure 3. Net sediment erosion and accretion in the vicinity of the gaussian headland. [Figure showing accretion of sediment at the tip of the headland and the in the lee of each side of the sandbank showing the initiation of the sandbank] 
Flow past Cape Levillain, located in Shark Bay is shown on Figure 4. We plan to conduct field measurements at this site over the nest two months. These results are considered preliminary as no validation studies of the model have been undertaken as yet but are used to plan the field measurement program.

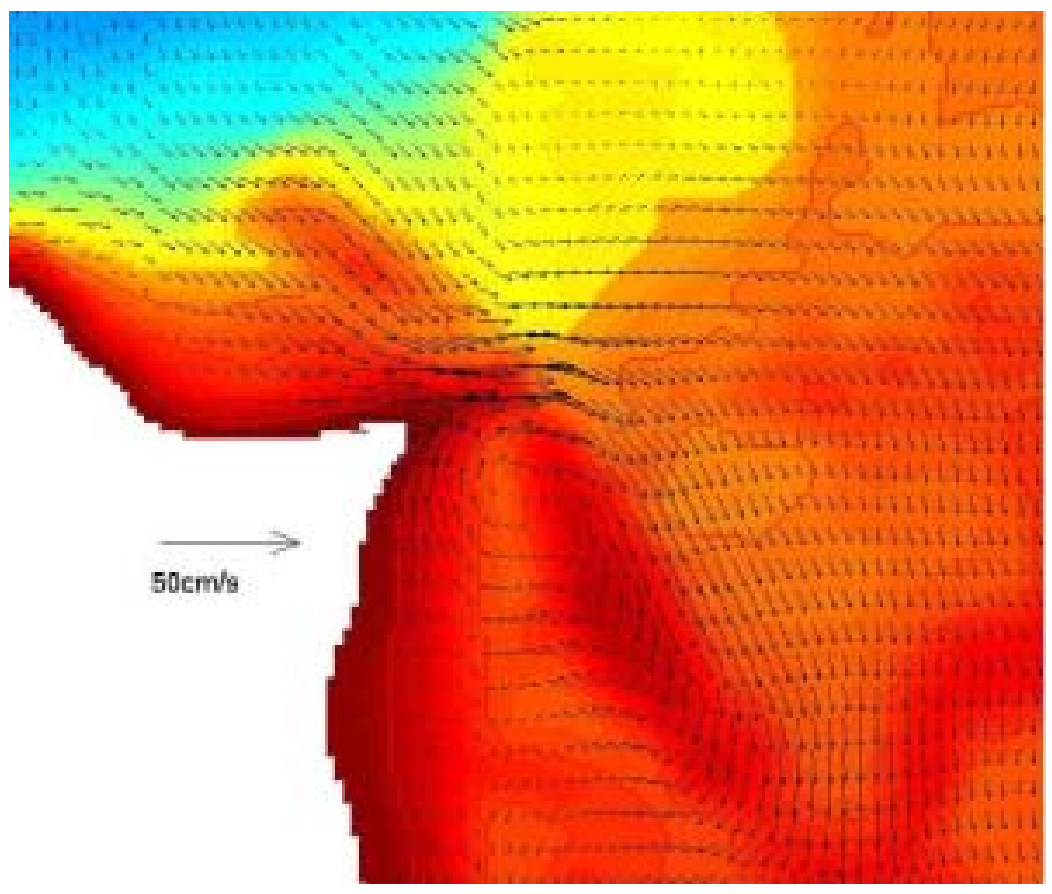

Figure 4. Tidal residual flow around Cape Levillain [Figure showing residual tidal currents offshore Cape Levillain showing an eddy on the lee side of the headland but not centred on the sandbank.]

\section{IMPACT/APPLICATIONS}

Initial results support the initial hypothesis that the 'flow in a tea-cup' analogy is not applicable for the formation of headland associated linear sandbanks. Development of the morphological model will indicate more conclusive results and processes responsible for the formation of these sedimentary features.

\section{TRANSITIONS}

The results obtained from this study is very preliminary. We are interacting with the scientific personnel from the Souhampton Oceanography Centre (UK) to validate and exchange information with regard to the Portland Bill application. 


\section{RELATED PROJECTS}

The coastal oceanography group undertakes fundamental and applied research projects in coastal oceanography, in particular on coastal and estuarine sediment dynamics, nearshore processes and circulation and mixing on the continental shelf. Current and recent projects appear on the University of Western Australia, Centre for Water Research, Coastal Oceanography home page (http://www.cwr.uwa.edu.au/space/CoastalOceanography/index.html). A summary version may also be found at: http://www.ehis.navy.mil/onrnews/butler/metoc-00-01.doc .

\section{REFERENCES}

De Vriend H. J, Zyserman J., Nicholson J., Roelvink J. A., Pechon P. and Southgate H. N. 1993. Medium term 2DH coastal area modelling. Coastal Engineering, 21, 193-224.

Green T. M. 1998. Circulation patterns in van Diemans Gulf, Northern Territory. Hons thesis. Department of Environmental Engineering, The University of Western Australia.

Pattiaratchi C. B. 1998. Modelling the three dimensional structure of headland flows and formation of sandbanks. Proc. $9^{\text {th }}$ Physics of estuaries and coastal seas conference. Matsuyama, Japan, 89-92.

Pattiaratchi C. B. and Collins M. B. 1987. Mechanisms for linear sandbank formation and maintenance, in relation to dynamical oceanographic observations. Progress in Oceanography, 19, 117-166.

Pattiaratchi C. B., Hammond T. M. and Collins M. B. 1986. Mapping of tidal currents in the vicinity of an offshore sandbank from remotely-sensed data. Int. J. of Remote Sensing, 7: 1015-1029.

Pingree R. D. 1978. The formation of the Shambles and other banks by tidal stirring of the seas. Journal of the Marine Biological Association, UK, 58,211-226.

Wright L. D. 1995. Morphodynamics of inner continental shelves. CRC Press, 241pp.

\section{PUBLICATIONS}

None

PATENTS

None 